\title{
An analysis of integrative outcomes in the Dayton peace negotiations
}

Article in International Journal of Conflict Management - December 2000

DOI: 10.1108/eb022846

CITATIONS

5

2 authors:

\section{Nimet Beriker}

Peace Research Institute Oslo

25 PUBLICATIONS 98 CITATIONS

SEE PROFILE
Tijen Demirel-Pegg

Indiana University-Purdue University Indiana... 5 PUBLICATIONS 37 CITATIONS

SEE PROFILE 


\title{
CASE STUDY
}

The International Journal of Conflict Management

2001, Vol. 11, No. 4, pp. 359-378

\section{AN ANALYSIS OF INTEGRATIVE OUTCOMES IN THE DAYTON PEACE NEGOTIATIONS}

\author{
Nimet Beriker-Atiyas \\ Sabanci University, Turkey \\ Tijen Demirel-Pegg \\ Bilkent University, Turkey
}

The nature of the negotiated outcomes of the eight issues of the Dayton Peace Agreement was studied in terms of their integrative and distributive aspects. In cases where integrative elements were found, further analysis was conducted by concentrating on Pruitt's five types of integrative solutions: expanding the pie, cost cutting, non-specific compensation, logrolling, and bridging. The results showed that real world international negotiations can arrive at integrative agreements even when they involve redistribution of resources (in this casi redistribution of former Yugoslavia). Another conclusion was that an agreement can consist of several distributive outcomes and several integrative outcomes produced by different kinds of mechanisms. Similarly, in single issues more than one mechanism can be used simultaneously. Some distributive bargaining was needed in order to determine how much compensation was required. Finally, each integrative formula had some distributive aspects as well.

Integrative and distributive bargaining are two important conceptual constructs of the negotiation literature. It would not be wrong to argue that the terminology was inspired first by the categories and techniques of game theory. Accordingly, Rapoport's (1960) work on "Fights, Games and Debates" and Schelling's (1960) "Strategy of Conflict" are important points of departure. In the behavioral tradition,

Note: The authors thank to Dean Pruitt, Izak Atiyas, Scott Pegg, the editors of the International Journal of Conflict Management and the three anonymous reviewers for their comments, suggestions, and general assistance in preparing this paper. The article is a version of Tijen Demirel-Pegg's (1998) unpublished master's thesis; Analysing negotiated outcomes: Integrative agreements at the Dayton Peace Negotiations, Bilkent University. 
Walton and McKersie (1968) first made the distinction between distributive and integrative bargaining within the context of labor management negotiations. They defined distributive bargaining as "a hypothetical construct referring to the complex system of activities instrumental to the attainment of one party's goal when they are in basic conflict with those of the other party" (p. 4). Integrative bargaining, on the other hand, refer "to the system of activities which is instrumental to the attainment of objectives which are not in fundamental conflict with those of the other party and which therefore can be integrated" (p. 5).

Since then, integrative and distributive bargaining has become an essential perspective in understanding, analyzing, and teaching negotiations. An important aspect of this literature is the treatment of integrative and distributive bargaining as essentially mutually exclusive processes. Based on these two constructs, different conceptual variations have been created by various authors. Positional bargaining versus interest based bargaining (Fisher \& Ury, 1981), competitive versus cooperative bargaining, bargaining versus problem solving (Hopmann, 1995), win-lose versus win-win negotiations (Lewicki, Litterer, Minton, \& Saunders, 1994), and creating versus claiming value (Lax \& Sebenius, 1986) are concepts used to explain similar phenomena. In these studies the terms distributive and integrative were not always used to refer to "situations" as in the case of Thompson (1990), but also to "the process" (Donohoe \& Roberto, 1996; Walton \& McKersie 1968) and sometimes to the "outcome" of negotiation (Pruitt, 1981).

Experimental researchers have conducted several studies to measure the impact of different variables on integrative outcomes. The affect of framing (Bottom \& Studt, 1993; Simons 1993; Mannix, Tinsley, \& Bazerman, 1995); the mobility of negotiators (Mannix et al., 1995); time pressure (Yukl, Malone, Hayslip, \& Yamin, 1976; Carnevale \& Lawler, 1986) negotiator's experience (Thomson 1990); ingroup identity (Kramer \& Brewer 1984); depersonalized trust (Brewer 1981); and social motives, trust, and punitive capability (De Dreu, Giebels, \& Van de Vliert, 1998) on integrative outcomes have been studied. Effective integrative negotiation often involves information exchange (Thomson 1991), trust (Kimmel, Pruitt, Mgenau, Konar-Golband, \& Carnevale, 1980), the expectation of future cooperative exchange (Ben Yoav \& Pruitt, 1984), and third parties to facilitate exchanges.

Literature on negotiations often draws a direct link between parties' distributive behavior and the achievement of a distributive outcome, and vice versa. Accordingly, while behaviors such as threats, commitments, bluffs, and concealment of information are presumed to lead to distributive outcomes, behaviors such as, rewards, promises, joint problem solving, and frank and open communication are expected to induce integrative solutions (Pruitt, 1981; Lewicki et al., 1994).

Different authors have challenged the distinction between integrative and distributive bargaining. Lax and Sebenius (1986) explicitly argued that typical negotiation processes involve both integrative (value creating) and distributive (value claiming) behavior. In their view, "No matter how much creative problem solving enlarges the pie, it must still be divided; value that has been created must be claimed" (p. 33). Bartos (1995) modelled integrative bargaining as distributive bargaining with a search process, and showed that integrative negotiation is not necessarily timeefficient, and the search process per se does not create an amicable environment. Only 
a joint search process (face to face bargaining) creates an amicable environment. Beriker (1995) suggested that real world international negotiations involve strategies and tactics of both distributive and integrative bargaining together with all tactics, creating a situation which helps to converge distributive bargaining into integrative negotiations. Putnam's (1990) review of research shows three main inclinations in elaborating the relationship between integrative and distributive bargaining. The first is the separate model, which assumes the two processes to be mutually exclusive events. The second is the stage model, which claims that bargainers typically start with distributive attitudes and then move toward an integrative mode. The third is the interdependence model, which assumes that integrative and distributive tactics are dependent on each other for their existence. In the context of hostage negotiations, Donohoe and Roberto (1996) showed that each model could emerge depending on the contextual parameters. Atiyas and Beriker (1997) addressed the importance of formal modelling in describing integrative and distributive situations and in advising related processes.

Studies on integrative negotiation are mostly based on the findings of the experimental research tradition. What is missing, however, is the role of integrative negotiation in real world diplomatic negotiations. Studies on diplomatic negotiations often involve historical, legal perspectives, and case studies; and they are not particularly focused on integrative aspects of real world negotiations.

\section{Negotiated Outcomes}

Distributive outcomes are attained through the allocation of fixed sums of goods among the negotiating parties. It often involves a settlement that is somewhere in between the resistance points of the two parties (the bargaining zone). A good illustration of a distributive bargaining situation is a haggle over the price of a single item, such as a second-hand computer. In such a bargaining situation, generally, negotiators start with an asking price (target point) and through give and take, they try to finalize the process as close to the other party's resistance point as possible. The resistance point is the price beyond which the party refuses to give any concession (Lewicki et al., 1994). Cooptation is an extreme form of distributive outcome where one party gets all its demands and the other gets nothing.

Integrative outcomes, on the other hand, allow agreements that satisfy both parties' needs. They are settings in which participants can consider multiple issues at the same time and make trade-offs to generate relatively high joint gains (De Dreu, Weingart, \& Kwon, 2000) According to Pruitt and Rubin (1986) social motives are the key to integrative agreements. The dual concern model assumes two types of concerns: concern about own outcomes and concern about the other's outcomes. The model predicts that integrative agreement are more likely to be achieved when a negotiator has a strong concern about both its own and the other party's outcomes.

The integrative bargaining literature suggests five basic types of mechanisms to achieve outcomes that deliver higher joint benefits to the parties (Rubin, Pruitt, \& Kim, 1994). In logrolling, each party gives concessions on issues that are of relatively low priority to themselves and high priority to tire other party typically in 
exchange for concessions by the other party on issues with the opposite characteristics. In cost cutting, one party gets what $\mathrm{s} / \mathrm{he}$ wants and the other gets compensated for the losses s/he incurs. Nonspecific compensation occurs when one party gets what $\mathrm{s} / \mathrm{he}$ wants and compensates the other. Hence it is similar to cost cutting except for the fact that the compensation is not related to any of the issues directly bearing on the bargaining problem. Bridging is also similar to logrolling. However, here, trade takes place not between the issues, which were originally on the bargaining table, but between the interests underlying those issues. Finally, in expanding the pie, the parties simply expand the amount of resources available for negotiations.

In this study, the five mechanisms of integrative negotiations are used to analyze the nature of the negotiated outcomes of the Dayton Peace agreement. To the best of our knowledge, it is the first time that these categories have been used to analyze a real world diplomatic negotiation.

\section{Method}

In order to be able to formulate the negotiated outcomes of the Dayton Peace negotiations, according to different agreement mechanisms, the following analytical points need to be identified: (a) the initial positions of the parties - aspiration levels and resistance points, to depict distributive outcomes; (b) the underlying interests behind the positions-for outcomes that involve bridging, nonspecific compensation, and cost cutting; (c) priorities placed on the issues - for logrolling, and (d) the actual outcomes i.e., what the parties get at the end of the negotiation process - for all outcomes. Similarly, identification of the issues and the parties is an additional task for the analysis. For this purpose, the following six questions are formulated:

1. What was the issue/sub-issue?

2. Who were the negotiating parties to this issue/sub-issue?

3. What was each party's position concerning this issue/sub-issue?

4. Why did the parties take such positions concerning this issue/sub-issue; what were the underlying interests?

5. What were the priorities of each party concerning this issue/sub-issue?

6. What did each party get at the end of the negotiations?

In this research, the above questions were systematically asked and answered for each issue of the Dayton negotiations to depict the nature of the outcomes and mechanisms used for the attainment of those outcomes. Therefore, the account of each negotiation presented in the next section follows the same format, that is, a point- by- point presentation of the answers to the above questions.

The answers to the questions were generated by analyzing: (a) Primary news resources including Keesing's Record of World Events, Facts on File, Summary of World Broadcasts, and OMRI Daily Digest, for the period 1991-1995; (b) the text of the Dayton Agreement; (c) daily newspapers; and (d) memoirs of the diplomats.

In this study, we defined parties as the official participants to the negotiations. Therefore, in referring to the parties, in the text, we used the names of each ethnic group, i.e., "Muslim-Croats" or "Bosnian Serbs." However, we did not use the names of the representatives of the ethnic groups to avoid a possible discussion on 
the issue of legitimacy of the representations. We treated parties' initial positions as parties' official negotiating positions at the beginning of the US involvement to the conflict in February 1994. Final positions are the actual outcomes of the Dayton Peace Talks.

Accordingly, in the analyses, an outcome will be called "distributive" (a) if a fixed resource (land, money, military equipment, etc.) is simply shared among the parties; (b) if one party acquires the total of what he/she asks for and the other party obtains nothing; and (c) if the parties achieve an agreement by giving concessions from their opening demands and settle with a position closer to their resistance point. (In this case, identification of target points, second best positions, and resistance points from documentary data is essential in order to claim an outcome as distributive.)

We label an outcome as "non-specific compensation" when one party gets the total of what he/she originally asks for, and the other party receives some items which are not related to the original negotiated issues.

Similarly an outcome is called "cost cutting" when one party gets the total of his/her demands and the other party obtains some items, related to original issue, in order to decrease the cost occurred.

"Logrolling" is identified if parties express different priorities on an issue and exchange concessions on the items that are of relatively low priority to themselves. (To be able to detect logrolling identification of parties' priorities from documentary data is essential.)

Finally, an outcome is called "bridging" if parties come up with a new and creative solution which satisfies all parties' interests.

\section{Background to the Negotiations}

The Socialist Federal Republic of Yugoslavia, established in 1945 was comprised of six republics: Bosnia-Herzegovina, Croatia, Macedonia, Montenegro, Serbia, and Slovenia, and two fully autonomous regions within Serbia: Kosova in the south and the Vojvodina in the east. In keeping with the escalating nationalist movements and ethnic tensions, Slovenia and Croatia declared their independence from the Yugoslav Federation on June 25, 1991. Furthermore, toward the end of 1991, Macedonia and Bosnia-Herzegovina took concrete steps toward independence. On October 15, Bosnia-Herzegovina declared its sovereignty. ${ }^{1}$

The Croat, Muslim, and Serb forces began fighting for control of strategic areas after the republic declared full independence on March 3, 1992. The military situation deteriorated rapidly and by mid-1992 international concern began to grow with the realization of how much the situation had deteriorated, and could get even worse as the Serbs declared their intention of linking Serbia proper with the Serb enclaves in Bosnia and Croatia. Given all these developments, the international community launched several peace initiatives in order to end the conflict. The

Accounts of the negotiations are based on news sources including Keesing's Record of World Events, Facts on File, Summary of World Broadcasts, OMRI Daily Digest, and International Herald Tribune, for a period of 1991 -1995. 
European Community (EC) made the first attempt. This was followed by the UN and the EC. The Vance-Owen mediation effort was based on the division of BosniaHerzegovina into ten provinces within a decentralized state.

Another UN-EC peace initiative was mediated by Lord Owen and Thorwald Stoltenberg but did not bring tangible results.

The first time the U.S. acted decisively to end the conflict was in February 1994. The US strongly backed the establishment of a confederation of the MuslimCroat regions of Bosnia-Herzegovina, and on March 18, the federation agreement was signed.

Russia, Britain, France, Germany, and the U.S. under the name of the "Balkan Contact Group" began the next peace attempt in April 1994. The Contact Group proposed to divide Bosnia-Herzegovina on the basis of a $49-51 \%$ division in favor of the Muslim-Croat side. This proposal later constituted the basis for the new US peace initiative.

It was the Dayton Peace Process that produced an agreement bringing an end to the war in Bosnia-Herzegovina through effective U.S. mediation. A very critical aspect of this US peace initiative was the pressure used by the U.S. through the NATO air strikes to bring the parties, mainly the Bosnian Serbs, to the negotiation table. The three main issues which were finalized at the Dayton negotiations were: (a) the territorial issue; (b) the constitutional issue; and (c) the issue of Sarajevo.

The US Peace initiative began in the middle of August, and as a consequence of the mediation of Richard Holbrooke, the Dayton Peace Agreement was signed on December14, 1995 in Paris (see Holbrooke, 1998, for a detailed account). Table 1 summarizes the milestones of the U.S. Peace Process.

The territorial issue consists of four sub-issues, which are (1) the percentage of territory each party would get; (2) control of Gorazde and the land link between Sarajevo and Gorazde; (3) control of Eastern Slavonia; and (4) the Posavina Corridor and Brcko. The constitutional issue comprises three sub-issues, which are (1) the integrity of the state of Bosnia-Herzegovina; (2) political authorities of the state; and (3) the name of the state. The issue of Sarajevo has no sub-issue.

\section{Analysis}

\section{Percentage of Territory Each Party Would Get}

Long before the US Peace Initiative, which was unveiled on August 9, 1995, the Contact Group, in May 13, 1994, proposed the division of Bosnian territory such that Bosnian Serbs would control $49 \%$ of the land and the Muslim Croat side would control 51\%. At that time, the Bosnian Serbs had rejected the $49 \%$ proposal as they were controlling $70 \%$ of the country and had military supremacy on the ground. 


\section{Table 1}

\section{Milestones in the US Peace Process}

Date

August 16, 1995

August 28, 1995

August 30, 1995

September 2, 1995

September 6, 1995

September 8, 1995

September 16, 1995

September 26,1995

October 5, 1995

November 1, 1995

November 21,1995

December 14, 1995
Event

The introduction of the U.S. Peace Plan and the beginning of Holbrooke's mediation effort

Bosnian Serb shelling of a market place in Sarajevo

The beginning of NATO air strikes against Bosnian Serbs

The suspension of NATO air strikes against Bosnian Serbs

The resumption NATO air strikes against Bosnian Serbs

The Geneva Accord The question of integrity of the state was worked out

The suspension of NATO air strikes against Bosnian Serbs

The New York Accord

The constitutional arrangements for BosniaHerzegovina were worked out.

The Cease-fire Agreement

The beginning of the peace talks in Dayton, Ohio

The text of the Dayton Peace Agreement documents has been initialled in Dayton.

The Dayton Peace Agreement has been signed in Paris.

At the beginning of the Dayton talks the Muslim-Croat side said that any peace plan's demarcation should not be more disadvantageous than the plan of the Contact Group, which indicated that the percentage of the territory they would control should not be less than 51\%. The Bosnian Serbs, on the other hand, stated that they would consider it "painful" if they would get less than $70 \%$ of the territory as they then controlled $70 \%$ of the country. Furthermore they could consider it "unjust" if they would get less the $64 \%$ territory. The final territorial division in the Dayton Agreement gave $49 \%$ of the country to the Serb Republic while $51 \%$ of the country would remain under the Federation of Bosnia-Herzegovina.

There were two important events, which were decisive in making the Bosnian Serbs accept the 49-51\% division: The Croat offensive and the NATO air strikes. The successful operation launched by the Croatian forces in early August 1995 to 
recover control of the Krajina region from the rebel Croatian Serbs, caused the Bosnian Serbs to lose territory on the ground and supremacy in the battlefield. On August 30, 1995, as a direct response to the Sarajevo mortar bombing by Bosnian Serbs, NATO launched "Operation Deliberate Force" and bombed Serbian targets. By the middle of September, the Bosnian Serb-controlled territory had already decreased from 70\% to 50\% (International Herald Tribune, 9 September 1995).

The solution that was reached as a result of the peace process seems to be an imposition rather than a process where the parties negotiated for joint benefits. The US imposed this division by implicitly balancing the military situation in accordance with the $49-51 \%$ basis. Therefore, if the Bosnian territory is considered as a pie, the pie was divided on a $49-51 \%$ basis. Issue linkages were not made in the achievement of the final formulation. Within this framework, this solution is best described as a distributive outcome.

\section{Control of Gorazde and the Land Corridor between Sarajevo and Gorazde}

Gorazde is a town that is close to the Serb border (Figure 1 presents a map of the municipalities of Bosnia-Herzegovina). The Muslim-Croat side wanted to have control of Gorazde with a land link between Gorazde and Sarajevo. The underlying interest of this demand was to connect the Muslim enclave of Gorazde with the rest of the Muslim territory by linking it to Sarajevo. Second, such a corridor would make it possible for the Federation of Bosnia-Herzegovina to build two or three hydroelectric plants, which had previously been planned. Thus, the Muslim-Croat side wished to have control of Gorazde and wanted to link Gorazde with the rest of their territory to lift the blockade of the city, but more specifically to link Gorazde with Sarajevo to be able to build hydroelectric plants. Both of these demands were important for the survival and the development of that city.

The Bosnian Serbs also wanted Gorazde. They had three underlying interests of which the first was to have integral Bosnian Serb territory. Bosnian Serbs wanted integral, not disconnected territory. If Gorazde remained a Muslim town surrounded by Serb territory, this would, they claimed, obviously prevent the realization of Serbian territorial integrity. What is more, the Bosnian Serbs wanted to remove the last vestiges of the Bosnian Muslim community from their borders and thus asserted that Gorazde, a Muslim enclave, should be controlled by the Bosnian Serbs. The second reason was that a strategic route connecting much of the Bosnian Serb territory in the eastern Bosnia to the coal rich region of BosniaHerzegovina, runs through Gorazde. The Bosnian Serbs wanted the control of that important road. Finally, the Bosnian Serbs wanted to remove the possibility of any connection between the Muslims living in Yugoslavia's Sandzac region and the Muslims in Gorazde. Just like the Muslim-Croat side, the Bosnian Serbs also made their demands over Gorazde clear at the beginning of the peace process.

Although both parties did not give up their demands over Gorazde, an agreement was reached at the Dayton Peace Talks. According to this agreement, 
Figure 1

Municipalities of Bosnia-Herzegovina 
Gorazde would remain under the control of the Muslim-Croat side and would be open to Sarajevo with a wide corridor, which at its narrowest point was $8 \mathrm{~km}$ wide, on average $10-15 \mathrm{~km}$ wide, sometimes $30 \mathrm{~km}$. wide. This meant that the MuslimCroat side would have a belt of territory wide enough to build the hydroelectric plants. The Bosnian Serbs, on the other hand, would control Mrkonjic Grad, Sipovo, Ozren, Doboj, Modrico, Dervanta, (Bosanski) Brod, Samoc and Brcko. Visegrad, Srebrenica and Zepa would also remain Serb.

Control of Srebrenica and Zepa deserves special emphasis at this critical division of territory, as the Muslim-Croat side had demanded the return of Srebrenica and Zepa, two Muslim strongholds which the Bosnian Serbs had captured in July and which still remained under Bosnian Serb control. For the Muslim-Croat side, these two cities were important as the symbols of the Serb slaughter of the Muslim civilians during the war. With the loss of these cities both at the battlefield and the negotiation table, they were now symbols of the price of the peace.

As a result, the Muslim-Croat side's demand was fully satisfied by giving Gorazde to the Muslim-Croat Federation with a corridor to Sarajevo wide enough to build the hydroelectric plants. This solution can be identified as nonspecific compensation. In nonspecific compensation, one party completely gets what it wants, while the other party is compensated for its loss through some unrelated issue. The Muslim-Croat side got what it wanted; in return, the Bosnian Serb side was given Srebrenica and Zepa as compensation.

\section{Control of Eastern Slavonia}

In this problem, the negotiating parties were the Republic of Croatia and the rebel Croatian Serbs. The Republic of Croatia wanted to reintegrate Eastern Slavonia into its legal order, as it was at that time under the de facto control of the rebel Croatian Serbs.

The Republic of Croatia insisted on linking this problem to the peace process in Bosnia-Herzegovina for three important reasons. First of all, the Croats believed that if the sanctions against the Federal Republic of Yugoslavia (FRY) were lifted, there would not be any further negotiations on the reintegration of this area to the Republic of Croatia. The second reason was that there were 80,000 to 90,000 displaced refugees who wanted to return to their homes in Eastern Slavonia. Finally, this had been the richest area of the Republic of Croatia both industrially and agriculturally, with many factories and crude oil deposits.

The rebel Croatian Serbs did not want to give up the control of this region with the same underlying interest of possessing this oil rich area that had agricultural and industrial potential. The Republic of Croatia showed its determination in reintegrating this area to the Republic by threatening to liberate the occupied areas by force, in case no solution was found in the peace process.

Finally, on November 12, the Republic of Croatia and the rebel Croatian Serbs signed an agreement in Dayton concerning the problem of Eastern Slavonia. The parties agreed on a 12-month transitional period, which could be extended by another year upon the request of the signatories, under UN control, before Eastern Slavonia rejoined the Republic of Croatia. 
With this agreement, the peaceful reintegration of Eastern Slavonia would be facilitated. This agreement seems to satisfy the Croatian side while taking territory from the rebel Croatian Serbs. However, although there was no indication as to what the Serb side had received in exchange for its endorsement of the agreement, many diplomats in the Republic of Croatia said they expected that this agreement included a commitment to end sanctions against the FRY. In this case, the Republic of Croatia got what it wanted; in return, the Serbs received compensation in a totally unrelated field. Although the demand of the rebel Croatian Serbs was not met, in the sense that they lost Eastern Slavonia, another Serb demand, the lifting of sanctions against the FRY, was fulfilled. As a result, both the Republic of Croatia and the Serbs were satisfied, at least theoretically, through nonspecific compensation.

\section{Posavina Corridor and Brcko}

The Bosnian Serb demand of "compactness" of territory reflected itself also in the problem of the Posavina Corridor and the town of Brcko. Bosnian Serbs wanted to have Brcko, a town located at the northern part of Bosnia-Herzegovina, for themselves and to widen the Posavina Corridor, which was next to that town. The corridor was already under Bosnian Serb control, but the Bosnian Serbs wanted a broader line to connect the eastern and western parts of the Serb entity

The reason the Bosnian Serbs wanted to widen the corridor from its present 5 $\mathrm{km}$. to $18 \mathrm{~km}$. was that they wanted a territorial link wide enough to allow their planes to fly from Serbia to Banja Luka, a Bosnian Serb-dominated town. Such a demand also obviously served to realize the compactness of Bosnian Serb territory. On the other hand, the Muslim-Croat side explicitly stated that they would not give up Brcko and they refused to widen the corridor.

For the Muslim-Croat side the fundamental objective was simply the settlement of this problem, because the functioning of the railway from Place to Tuzla would be disturbed as long as this corridor remained problematic. However, the Muslim-Croat side still did not deviate from rejecting the widening of the corridor more than about $5 \mathrm{~km}$., which then was the actual distance between the MuslimCroat and Bosnian Serb armies. The Muslim-Croat side also had a concrete reason for refusing to compromise over the control of this corridor, as they hoped to cut through this strip of land to allow access to the Sava River on the Croatian border.

Both parties were so reluctant to compromise on this problem that the Dayton Peace Talks almost failed. This issue remained unresolved at the Dayton Peace Talks. In the end, Brcko and the Posavina Corridor issues were left to international arbitration, which was to decide on the fate of the corridor no later than one year after the peace agreement came into force. In this way, this problem was prevented from endangering the whole peace agreement.

\section{Integrity of the State of Bosnia Herzegovina}

The Muslim-Croat side was in favor of an integral Bosnia-Herzegovina. They wanted a peace solution based on the sovereignty and territorial integrity of BosniaHerzegovina. In contrast, the Bosnian Serbs were not in favour of an 
integral Bosnia-Herzegovina, as their ultimate goal was to establish a unitary state for all Serbs.

The reason the Muslim-Croat side wanted an integral state was to prevent the partition of Bosnia-Herzegovina. Once an independent Serb Republic was established as a consequence of such a partition, the Muslim-Croat side feared that this independent republic would unite with the FRY. In fact, the desire for the Bosnian Serbs to press for a union of Bosnia-Herzegovina rather than a single state, and to insist on having the right to establish confederal links, confirmed the fears of the Muslim-Croat side in this regard. During the negotiations the parties gave different signals regarding their positions and priorities on the issue. For example, when the Bosnian Serbs and the FRY declared that a joint Bosnian SerbYugoslav delegation would attend the peace talks, they stated that this would be a precursor of the confederal links between them. For the Muslim-Croat side, however, the most sensitive sub-issue was the Serb entity in Bosnia-Herzegovina. They could tolerate a large degree of autonomy and special ties for the Serb entity with the FRY, but they would not accept the establishment of a Serb republic or a confederation between the FRY and the Serb entity. They wanted a unitary Bosnian republic.

Two important accords that were decisive in the establishment of the state of Bosnia-Herzegovina: the Geneva Accord and the New York Accord. The Geneva Accord deserves special emphasis, because the problem of integrity of BosniaHerzegovina was solved, to a great extent, with this accord. According to the Geneva Accord, Bosnia-Herzegovina would be a single state within its present borders, but divided into two entities: the Federation of Bosnia-Herzegovina and the Serb Republic. Thus, Bosnia-Herzegovina's international status as a single state within its present borders would be maintained, but $51 \%$ of its land would be controlled by the Federation, composed of the Bosnian Muslims and Bosnian Croats, while $49 \%$ of its land would be controlled by the Bosnian Serbs. These two entities would also have the right to establish parallel special relations with the neighboring countries.

The Geneva Accord had different implications for the Muslim-Croat side and the Bosnian Serbs. For the Muslim-Croat side, the integrity of the state was important, and with this accord the notion of a unitary state was preserved. Thus, the dream of Greater Serbia was juridically over. The Muslim-Croat side obviously made a concession by accepting the Serb entity, but for them, the division of Bosnia-Herzegovina into two entities signified a division "within" the country, rather than a division "of the country. International recognition belonged to the state of Bosnia-Herzegovina, and the two entities making up the state of BosniaHerzegovina were not internationally recognized according to the Geneva Accord. Since the Serb Republic was not independent, such a concession could be tolerated.

A second concession the Muslim-Croat side had made was the recognition of the "special relationship" between the Bosnian Serbs and the FRY. The problem was that the extent of this "special relationship" was not specified. Later in the Dayton agreement it was stipulated that such a relationship should honor the sovereignty and territorial integrity of the state of Bosnia-Herzegovina, and any 
agreement on this should be approved by the parliament of Bosnia-Herzegovina. Furthermore, integration with other states was not permitted.

For the Bosnian Serbs, the Geneva Accord was important as for the first time, the Serb Republic had been officially recognized. In addition, each entity was permitted to be self-governing under its own constitution. The Bosnian Serbs and the FRY perceived this to be a guarantee of independence for the Bosnian Serbs.

The above account shows that the final settlement to the question of BosniaHerzegovina's integrity can be classified as a distributive agreement. Both parties' initially declared positions were opposing. The Muslim-Croat side demanded an integral state while, on the other hand, the Bosnian Serbs anticipated an independent state with special ties to the FRY. During the talks, the Muslim-Croat side made concessions by accepting the Serb entity. Similarly, Bosnian Serbs made concessions on the establishment of confederal links with the FRY. The distributive agreement was that Bosnia-Herzegovina would be a single state within its present borders, but divided into two entities with no confederal link with the FRY.

\section{Political Authorities of the State}

The difference between the Muslim-Croat orientation towards an integral state and the Bosnian Serb orientation towards partition manifested itself in negotiations over the political authorities of the state of Bosnia-Herzegovina. The Muslim-Croat side wanted the creation of a strong central government, that is, the establishment of democratic institutions, such as an assembly, a presidency, and a constitutional court in which the Bosnian Serbs would not be able to block the decision-making processes \{International Herald Tribune, 26 September 1995). The Bosnian Serbs, on the other hand, wanted to have institutions in which the Bosnian Serbs had equal rights in every issue with the Muslim-Croat side.

The Muslim-Croat side was anxious that the Bosnian Serbs would prevent the functioning of the joint institutions of the republic, by blocking every process. Thus, they wanted to organize the institutions so that the Bosnian Serbs could not block normal life. If the joint institutions would not function, one day the Bosnian Serbs might claim that the idea of republic status did not work, and use this claim as a justification for secession from the Republic of Bosnia-Herzegovina. Obviously, this would again mean the partition of the country. Therefore, the current interest of the Muslim-Croat side was to provide preconditions for the reintegration of Bosnia-Herzegovina. A legal precondition for this had already been set out by the Geneva Accord, and now the constitutional prerequisites and institutions that would enable the reintegration of Bosnia-Herzegovina had to be worked out.

The Bosnian Serbs, on the other hand, wanted to have institutions in which they had equal rights with the Muslim-Croat side. The underlying interest was to prevent the political suppression of the Bosnian Serbs by the Muslim-Croat Federation, which was likely to happen in a parliament in which the Muslim-Croat side held the majority. A second underlying interest was to maintain the existence, as well as the equality of the Serb entity.

In this context, the composition of the assembly and presidency and their decision-making procedures were important aspects of the problem. According to 
the New York accord, the future set-up would involve a parliament or a national assembly, a collective presidency and a constitutional court. The members of the parliament and presidency would be elected through free and democratic elections that would be held in both entities. Two-thirds of the members of the parliament or the national assembly would be elected from the Federation of Bosnia-Herzegovina (the Muslim-Croat side), and 1/3 from the Serb Republic (the Bosnian Serb side). In this parliament or assembly, the decisions on any issue would be taken by majority vote, but at least $1 / 3$ of each entity should back up the decision and vote in favor. The presidency would have the same composition, of which $2 / 3$ of its members would be from the Federation, and 1/3 from the Serb Republic. The decisions would also be taken by majority vote. However, if $1 / 3$ of the total members of the presidency disagreed with a decision and declared that that decision was destructive to a vital interest of the entity or entities, the decision would be referred back to the appropriate entity's/entities' parliament.

The Dayton Peace Agreement did not change the essence of the New York Accord. It specified the numbers of the membership of the assembly and the presidency, but did not alter their decision-making procedures. Thus, the right to veto for each entity prevailed. The Muslim-Croat side found the Dayton Peace Agreement satisfactory as it had established institutions for a functioning state Thus, they had achieved the aim of having a strong central government in BosniaHerzegovina. The Bosnian Serbs were also satisfied as they gained full equality and ensurance to handle their own affairs independently. In addition, they gained the right to veto, something that ensured the protection of the Serb people.

This solution is best characterized as bridging. In bridging parties find a solution that fulfills everybody' underlying interests. In this issue, the MuslimCroat side's underlying interest, the establishment of the legal and constitutional preconditions that would prevent Serb secession, was realized by the establishment of functional central institutions of governance. The veto power satisfied the Bosnian Serbs's interest of preventing the political suppression of the Bosnian Serbs by the Muslim-Croat majority.

\section{Name of the State}

Since the beginning of the peace process, the Muslim-Croat side stated that Bosnia-Herzegovina should remain a republic. The Muslim-Croat side wanted to have an integral Bosnia-Herzegovina and therefore preferred that the state would have a name such as "the Republic of Bosnia-Herzegovina." Their underlying interest was to keep the integrity of the state in order to prevent the secession of the Bosnian Serbs.

The initial demand of Bosnian Serbs was for the division of the country. Therefore, even negotiations over the name of the state of Bosnia- Herzegovina was perceived as irrelevant. The Bosnian Serbs were against calling the state a "republic". Later the Bosnian Serbs agreed to call the state a "union," but this was a compromise for them. But, between "union" and "republic," they preferred to call it a "union" rather than a "republic," as a union implies the existence of independent entities that would be united by a looser kind of superstructure. Their 
core concern was the recognition of a Serb entity within the state of BosniaHerzegovina, which would be a step toward the ultimate unification of the Serbs.

Finally, the state of Bosnia-Herzegovina, established by the Dayton Peace Agreement, was called the Republic of Bosnia-Herzegovina. In this issue, while one party's demands were fully satisfied, the other party did not get what it wanted. Therefore, this agreement can be classified as "cooptation," an extreme form of "distributive" outcome.

\section{Issue of Sarajevo}

The issue of Sarajevo was the third major issue on which the parties had divergent positions. The Muslim-Croat side wanted to have an undivided Sarajevo under its control, while the Bosnian Serbs wanted to control a part of Sarajevo. The Muslim-Croat side wanted Sarajevo to control vital communications and transportation sites. Second, they wanted a unified city, as a division of the city among hostile factions would create governance problems. However, the underlying interest of the Bosnian Serb side was quite different. The Bosnian Serb side was concerned about the future of the Serb minority living in Sarajevo. In addition, if they would control a part of Sarajevo, this would be a further indication of the legitimacy of their state within Bosnia-Herzegovina.

According to the Dayton Peace Agreement, Sarajevo remained under the control of the Muslim-Croat Federation and would be undivided. In return, the Bosnian Serb side got some districts of Sarajevo and also Pale, the provisional capital city of the Bosnian Serbs. Although the Bosnian Serbs did not have the same underlying interest for the districts of Sarajevo and Pale, still they were important areas for the Bosnian Serbs, and they would compensate for the loss of Sarajevo to a certain extent. In addition, the Bosnian Serbs had received guarantees concerning the rights of the Serb minority living in Sarajevo. The solution provided by the Dayton Peace Agreement, therefore, can be formulated as nonspecific compensation and cost cutting. In non-specific compensation, one party gets what it wants and the other party is compensated in some unrelated issue. In this issue, the outcome completely satisfied the Muslim-Croat demand and compensated the loss of the Bosnian Serb side. In addition, the Bosnian Serbs had received guarantees concerning the rights of the Serb minority living in Sarajevo. This can be formulated as cost cutting because the safety concerns of the Bosnian Serbs, caused by the loss of the city, were reduced through these guarantees.

\section{Conclusion}

This paper has used Pruitt's $(1977,1986)$ framework to analyze a real-world negotiation process. The analysis in the previous section revealed that among the seven sub-issues and one main issue, the negotiated outcomes of three sub-issues and of the main issue were integrative. In two of these sub-issues (the control of Gorazde and the land link between Sarajevo and Gorazde, and the control of Eastern Slavonia), non-specific compensation was used as the mechanism to reach integrative outcomes. In one sub-issue (the political authorities of the state), bridging was used. Finally, in one main issue (Sarajevo), cost cutting was used to 
reach integrative outcomes. Among the remaining four sub-issues, the negotiated outcome of the three sub-issues (the percentage of territory each party would get, the integrity of the state of Bosnia-Herzegovina and the issue of the name of the state) were distributive. Apart from that, one sub-issue (the Posavina Corridor and Brcko) was left to international arbitration. Table 2 summarizes our findings.

Table 2

Outcome results

Issue

The Territorial Issue

The Issue of Sarajevo

\section{Sub-Issue}

1. The percentage of territory (distributive)

2. The control of Gorazde (NSC)

3. The control of Eastern Slavonia (NSC)

4. The Posavina Corridor and Brcko (NA)

The Constitutional Issue

1. The integrity of the state of Bosnia Herzegovina (distributive)

2, The political authorities of the state (bridging)

3. The name of the state (distributive) (NSC and cost cutting)

Note: $\mathrm{NSC}=$ Non specific compensation, $\mathrm{NA}=$ Not applicable

Several conclusions can be drawn from these findings. First, the way that exchanges are made between and within the issues in the real world negotiations may be more complicated than what has been described in Pruitt and Rubin (1986). For example, in a single issue, more than one mechanism can be used simultaneously to find an agreement, e.g., in the issue of Sarajevo. In this case both nonspecific compensation and cost cutting were used to compensate the losses of Bosnian Serbs.

Another conclusion is that in all kinds of mechanisms there is a division of resources. This takes place either by sharing a resource that is pronounced at the negotiation table, e.g., through distributive bargaining, or by complicated sharings, that is exhanges of issues that were not at the negotiation table in the first place and through exchanges of priorities, or compensated concessions. Each integrative formulation conveys a distributive aspect as well. For example, in nonspecific compensation, while one party gets what it wants, the other party is compensated. How much compensation the other party would get and the timing of it are matters of distribution. For example, in the issue of the control of Gorazde and the land corridor between Sarajevo and Gorazde, the Bosnian Serbs were given Srebrenica and Zepa as compensation for the Muslim-Croat federation receiving a corridor to Sarajevo wide enough to build the hydroelectric plants. In this example, for instance if one party insists on getting the promised compensation in 6 months, and the other party insists on giving it in 12 months, this exchange may turn into a 
purely distributive bargaining. The same logic applies to cost cutting as well. In this form of agreement one party gets what it wants while the cost to the other party is reduced or eliminated. For example, in the issue of Sarajevo, the city as a whole remained under the control of the Muslim-Croat side, but the costs to the Bosnian Serbs were reduced by giving guarantees for the rights of the Serb minority living in Sarajevo. Again, a discussion of "the dimensions of the minority rights" to be extended, or the time framework in which these agreements are implemented may turn into a distributive process. Finally, in bridging, instead of fulfilling all interests, both parties' primary interests are met. In the issue of the political authorities of the state, for example, the primary interest of the Muslim-Croat side, the establishment of the legal and constitutional preconditions to pre-vent Serb secession was satisfied by the establishment of the institutions for the functioning of the state. The primary interest of the Bosnian Serbs in preventing their own political suppression was also satisfied through the veto power in the decision-making system. The result was a strong central government with a deci-sion-making system where the parties obtained veto power. Here as well, a dis-tributive potential is present, since the parties need to qualify what is "strong" central government or sufficient "veto" power.

As mentioned previously, one body of literature on negotiation suggests that distributive behavior leads to distributive outcomes and vice versa. However, this study showed that integrative agreements can take place in what Ikle (1964) calls "redistribution" negotiations, where the status quo is challenged by one party and the other takes a defensive stand. In other words, mechanisms to reach integrative outcomes can be used even in negotiations where parties redistribute existing resources (in this case, the redistribution of former Yugoslavia). This finding supports the view that most negotiations consist of overlapping processes, and contributes to the continuing discussion on the relative importance of competitive and cooperative processes in negotiation (Bartos, 1995; Hopmann, 1995; Dmckman, Martin, Nan, \& Yagcioglu, 1998).

Another conclusion is that in the specific case of the Dayton agreement the decision to talk reveals an interesting point about the role of the mediators. In this case, the US used pressure tactics both to bring the parties together and during the negotiations. The literature on third party intervention suggests that an agreement imposed by the mediator is unlikely to achieve stability in the long run (Mitchell \& Banks, 1996). We claim that in diplomatic negotiations this may not be the case. While the long-term stability of the Dayton agreements necessarily remains open to question, a mediator strong enough to use pressure tactics to convince parties to talk and reach an agreement is also expected to be strong enough to create conditions for sustainable peace by helping them in getting integrated to the international community, by creating new interdependences and incentive systems to cooperate, etc. Similarly, a muscled mediator is often a guarantor of the postagreement implementation stage, and this creates another incentive to cooperate, especially for the weaker party.

An important limitation of this methodology was the difficulty in learning the value each party attaches to a specific issue/sub-issue as well as the underlying interests of each party's position through documentary data. This had implications 
in the application of the "logrolling" category. Logrolling requires information about the parties' priorities. In diplomatic negotiations priorities are rarely made public. Therefore it was not possible to identify logrolling in this study. To overcome this limitation, it might be useful to interview the negotiators who are in the best situation to know the interests underlying their positions. However, this is a very costly method of gathering information. Another way that would help to reveal the underlying interests is referring to the records of the negotiations and relevant documents of the agreement. This is also not possible for the time being as the Dayton Peace Agreement is a recent agreement and the documents are still classified.

A second point that deserves emphasis is that this study analyzed the Dayton Peace Agreement at the issue and sub-issue level. It did not examine whether or how progress in one issue may have affected negotiations and outcomes in the rest of the issues. For example, it did not examine whether the parties perceived any trade offs between the territorial and constitutional issues, but instead analyzed each sub-issue of the territorial and constitutional issue in itself. In addition, although the analysis showed that the negotiated outcomes of individual issues were integrative outcomes that theoretically increased mutual benefits, our approach did not enable us to measure the magnitude of this increase.

In conclusion, we provided in this article an application of integrative categories to an international negotiation. This allowed us to give a fine-grained picture of the use of different mechanisms in a non-laboratory setting. Future research should look further into how different agreement mechanisms interact with each other across the issues. Multiple case studies of international agreements are needed to evaluate whether our findings can be generalized.

\section{References}

Atiyas, I., \& Atiyas-Beriker N. (1997, June). A strategic approach to integrative solutions.

Paper presented at the 10th annual conference of the International Association for

Conflict Management, Bonn, Germany. Ben-Yoav, O., \& Pruitt, D. G. (1984). Resistance to yielding and the expectation of coop-erative future interaction in negotiation. Journal of Experimental Social Psychology,

20,323-353. Beriker, N. (1995). Mediating regional conflicts and negotiating flexibility: Peace efforts in

Bosnia-Herzegovina. In D. Druckman \& C. Mitchell (Eds.) Flexibility in international

negotiation and mediation. Annals, 542, 185-201. (special issue) Bartos, O. J.

(1995). Modeling distributive and integrative negotiations. In D. Druckman \&

C. Mitchell (Eds.), Flexibility in international negotiation and mediation (special issue).

The Annals, 542, 48-60. Bottom, W., \& Studt, A. (1993). Framing effects and

the distributive aspect of integrative

bargaining. Organizational Behaviour and Human Decision Process, 56, 459-

474. Brewer, M. B. (1981). Ethnocentrism and its role in interpersonal trust. In M. Brewer, \& B.

Collins (Eds.), Scientific inquiry and the social sciences. San Francisco:

Jossey-Bass. Carnevale, P. J., \& Lawler, E. J. (1986) Time pressure and the development of integrative

agreements in bilateral negotiations. Journal of Conflict Resolution, 30, 636659. 
De Dreu, C. K. W., Weingart L. R., \& Kwon S. (2000). Influence of social motives on

integrative negotiation: A meta-analytic review and test of two theories. Interpersonal

Relations and Group Processes, 78, 889-905. De Dreu, C. K. W., Giebels, E., \& Van de Vliert, E. (1998). Social motives and trust in integrative negotiation: Disruptive effects of punitive capability. Journal of Applied

Psychology, 83, 408-122. Donohoe, W. A., \& Roberto, A. J. (1996). An empirical examination of three models of

integrative and distributive bargaining. International Journal of Conflict Management,

7,209-229. Druckman, D., Martin, J., Nan, A. S., \& Yagcioglu, D. (1998).

Dimensions of international negotiations: A test of Ikle's hypothesis (Course Teaching Note 3). Institute for the

Study of Diplomacy Publications, Washington, DC. Fisher, R., \& Ury, W. (1981). Getting to yes: Negotiating agreement without giving in.

England: Penguin Books. Holbrook, R. (1998). To end a war. New York:

Random House. Hopmann, P. T. (1995). Two paradigms of negotiation: Bargaining and problem solving. In

D. Druckman \& C. Mitchell (Eds.), Flexibility in international negotiation and

mediation. Annals, 542, 24-47. (special issue) Ikle, C. H. (1964). How nations negotiate. New York: Harper and Row. Kimmel, M. J., Pruitt, D. G., Mgenau, J.

M., Konar-Golband, E., \& Carnevale, P. J. (1980).

Effects of trust, aspiration, and gender on negotiation tactics. Journal of Experimental

Psychology, 38, 9-23. Kramer, R. M., \& Brewer, M. B. (1984). The effects of group identity on resource use in a

simulated commons dilemma. Journal of Personality and Social Psychology, 46, 1004-

1057. Lax, D., \& Sebenius, J. (1986). The manager as negotiator. New York: Free Press. Lewicki, R. J., Litterer, J. A., Minton, J. W., \& Saunders, D. M. (1994). Negotiation (2nd

ed.). Boston: Irwin. Mannix, E. A., Tinsley, C. H., \& Bazerman, M. (1995). Negotiating over time: Impediments

to solutions. Organizational Behaviour and Human Decision Process, 62, 241-251. Mitchell, C, \& Banks, M. (1996). Handbook of conflict resolution: The analytical problem

solving approach. London: Pinter. Owen, D. (1995). Balkan odyssey. London:

Cassel Group. Pruitt, D. G., \& Rubin, Z. J. (1986). Social conflict. New York: Random House. Pruitt, D. G. (1981). Negotiation behavior. New York: Academic Press. Pruitt, D. G., \& Lewis, S. A. (1977). The psychology of integrative bargaining. In $\mathrm{D}$.

Druckman (Ed.), Negotiations: Social-psychological perspectives (pp. 161-192).

London: Sage. Putnam, L. L. (1990). Reframing integrative and distributive bargaining: A process

perspective. In R. J. Lewicki, B. H. Sheppard, \& M. H. Bazerman, (Eds.), Research on

Negotiation in Organizations (pp. 3-30). Greenwich, CT: JAI Press. Rapoport, A. (1960). Fights, games \& debates. Ann Arbor: University of Michigan Press. Rubin, J. Z., Pruitt, D. G., \& Kim, S. H. (1994). Social conflict: Escalation, stalemate and

settlement. New York: McGraw-Hill. Schelling, T. C. (1960). The strategy of conflict. Cambridge, Mass.: Harvard University

Press. Simons, T. (1993). Search patterns and the concept of utility in cognitive maps: the case of

integrative bargaining. Academy of Management Journal. 36 (1), 139-156.

Thompson, L. (1991). Information exchange in negotiation. Journal of Experimental

Phsychology, 27, 161-179. 
Thompson, L. (1990). Negotiation behavior and outcomes: Empirical evidence and

theoretical issues. Psychological Bulletin, 108, 515-532. Walton, R. E., \& McKersie, R. B. (1968). A behavioural theory of labor negotiations. New York: McGraw-Hill. Yukl, G. A., Malone, M. P., Hayslip, B., \& Yamin, T. A. (1976). The effects of time pressure and issue settlement order on integrative bargaining. Sociometry, 39, $277-281$.

\section{Biographical Note}

\section{Nimet Beriker-Atiyas}

Faculty of Arts and Social Sciences

Sabanci University

81474 Tuzla , Istanbul Turkey

Phone/Fax: 90-216-483-92-45/90-216-483-92-50

Email: beriker@sabanciuniv.edu

Nimet Beriker-Atiyas received her doctorate from the Institute for Conflict Analysis and Resolution at George Mason University. Currently she is responsible for the establishment of a graduate program in conflict resolution at Sabanci University, Istanbul, Turkey. Her teaching and research interests are international negotiation and mediation; conflict resolution and foreign policy; simulation and content analysis. Her articles have appeared in Simulation and Gaming, Annals, Journal of Social Psychology, and Security Dialogue.

\section{Tijen Demirel-Pegg}

Department of International Relations

Bilkent University

06533 Bilkent, Ankara, Turkey

Phone:90-312-290 2010

Email: tijen demirel@hotmail.com

Tijen Demirel-Pegg is a Ph.D student in the Department of International Relations, at Bilkent University, Ankara, Turkey. This article is a version of her unpublished master's thesis, "Analyzing Negotiated Outcomes: Integrative Agreements at the Dayton Peace Negotiations, " Bilkent University, 1998.

Received: October, 161999

Accepted by Michael R. Roloff after two revisions: November 25, 